\title{
Kirchberg 3 October 2006: Three Decisions that Did ... Not Change the Future of European Taxes
}

Prof. dr. Pasquale Pistone, Associate Professor of Tax Law at the University of Salerno, Italy and EURYI-ESF Professor of International

and European Tax Law at the Wirtschaftsuniversität Vienna, Austria

3 October 2006. A day which could have, but did not, changed the destiny of Europe through three decisions.

On that day the European Court of Justice decided the Banca Popolare di Cremona case, involving the compatibility of the Italian business tax (Irap-Imposta regionale sulle attività produttive) with the common VAT system, the Scorpio case, dealing with equal treatment in the host state applying withholding taxes on non-residents, and the (non-tax) Fidium Finanz case, concerning the relations with third countries in respect of the supply of services into the EU by a nonEU national.

Banca Popolare di Cremona long catalysed the attention of the European tax community because of its potential implications on the Italian budget. Had the ECJ concluded that Irap interfered with VAT, Italy would have been obliged to an estimated repayment of over $€ 120$ billion, the highest ever to be recorded in a single case.

Until 3 October 2006 some authors, including myself, had expected this outcome. Others had feared that the retrospective application of such decision could sink the Italian budget together with the stability of Euroland and the EMU criteria. Others had feared repercussions on other Member States such as France and Spain, but especially Hungary with two cases already pending before the ECJ on business taxes). Others instead had feared that limiting the retrospective application to the moment of publication of the referral order (as suggested by Advocate General Tizzano in the first opinion on the Meilicke case) could have represented a dangerous precedent in simplifying the standards of legal protection for claims similar to those referred to the ECJ and already formally lodged on the day of its decision.

All such fears and expectations now belong to our common European tax history, together with the claims for reimbursement of Irap, made by the majority of Italian business taxpayers.

On 3 October 2006, the Grand Chamber of the European Court of Justice made its final ruling stating that Irap, and possibly also all other business taxes sharing its main features, does not interfere with the common VAT system, framing its arguments on a twostep approach analysis.

The ECJ used four main arguments to conclude that Irap does not interfere with the common VAT system.

1. Irap is charged on the net value of production regardless of the actual supply of goods and services.

2. Although the absence of input tax deduction is not decisive when ascertaining VAT interference, the Court argued that it is uncertain if the former tax will be borne by the consumer.

3. The amount of Irap included in the purchased goods and services cannot be easily ascertained.

4. Each taxpayer could shift the economic burden of Irap even for amounts exceeding the actual valueadded of goods and services that he/she had supplied, thus proving that Irap was not meant to be juridically shifted to the final consumer: a matter that in the Court's opinion proves the difference between Banca Popolare di Cremona and its most important predecessor, Dansk Denkavit.

Despite accepting the Court's decision, I believe that the missing legacy of Banca Popolare di Cremona has left an aura of uncertainty all around the scope of Article 33 of the Sixth VAT Directive: a provision that (until now) has given VAT very limited protection from external interference by Member States.

Certainly, the Court's decision made it unnecessary to state on the delicate issue of limiting the retrospective application in a case with an unclear pattern for invoking bona fide and very high budget repercussion because of the number of similar pending cases before national judges.

Nevertheless, when analysing the four arguments used by the European judges in dismissing the interference between Irap and VAT, one should also take into account the following issues.

1. No goods or services may escape Irap and VAT.

2. Its burden is in fact always shifted to the final consumer. Despite the absence of a legal mechanism of shift, it is hard to believe that Italian suppliers would bear the burden of Irap themselves, or shift it to persons other than consumers.

3. Although it is difficult to keep track of the actual value-added taxed by Irap, accepting such argument may encourage national systems to go around 
Article 33 of the Sixth VAT Directive by introducing taxes with complex methods to determine the taxable base in respect of transactions that directly or indirectly affect the turnover.

4. Insofar as the overall value-added of production remains subject to both Irap and VAT, the pattern does not really seem to differ from that of the Dansk Denkavit case. Shifting a tax burden that exceeds the actual value-added of goods and services supplied is another issue, mainly concerning the economic reaction of suppliers of goods and services, rather than the interference with VAT. For sure the Court's argument based on teleological interpretation is relevant. However, after all, shouldn't we protect the common VAT system and the internal market from any factual interference, rather than by looking at the intention?

Even if the other two cases (Fidium Finanz and Scorpio) decided on 3 October 2006 deal with different (tax and non-tax) issues, they still share the common pattern of addressing free movement of services in the relation to third countries supplied by a non-EU national (or, in the case of Scorpio, a person of uncertain nationality).

The Court had shown its clear intention of clarifying the relationship between the free movement of capital and payments and the other freedoms: a matter that is essential for a systematic approach to the relationship with third countries. Both cases gave the Court the occasion to do so exclusively in respect of free movement of services. The pending case Thin Cap Group Litigation Order will possibly do the same in respect of the right of establishment.

In the (non-tax) Fidium Finanz case, a non-EU national established in Switzerland supplied financial services to German resident recipients through electronic means without having the specific authorisation imposed by German law on all economic operators in the country. In the presence of a third country element, national judges referred the questions in respect of free movement of capital and payments by asking whether non-EU nationals may invoke such freedom in respect of services that, if supplied by an EU national, would have otherwise fallen under the scope of Article 49 of the EC Treaty.

Unlike in the Svensson and Gustavsson case, which dealt with third country recipients, though nationals of a country which had signed an Association Agreement, the Grand Chamber of the Court this time excluded that the service could be relevant for both the free movement of services and that of capital and payments.

Again, the Court followed a four-step reasoning to exclude the incompatibility of the national provision with European law.

1. The Court interpreted Article 50.1 of the EC Treaty in a way that the application of other freedoms only applies with a view to defining what represents a service under the scope of Articles 49 and $\mathrm{ff}$.

2. The Court excluded that the specific reference to the liberalisation of banking and financial services ... in step with ... [that] of movement of capital, contained in Article 51.2 of the EC Treaty, could imply a priority of the latter freedom over that to provide services, instead being merely directed to the introduction of secondary law.

3. The restrictive rules here aim to provide appropriate supervision against abusive banking and financial services to make free movement of services predominant over other freedoms.

4. Free movement of services does not apply to relationships with third countries until the EU Council gives effect to Article 49.2 of the EC Treaty, which explicitly refers to such situation.

Once more the expectations were different, but once more the Court's final verdict goes into the right direction, despite possible questionable statements on specific technical issues.

First, one may argue that banking and financial services are, by their own nature, connected to the movement of capital and therefore, the Court's reading of Article 50.1 of the EC Treaty should have implied the consequences of excluding the relevance of the free movement of services in this specific case, regardless of the second argument concerning the scope of Article 51.2 of the EC Treaty.

The third argument implicitly confirms the Court's great concern for abusive practices: a matter that is clearly perceivable in all recent tax cases involving the risk of double dipping, but which the Court disregarded in other non-tax cases, such as Überseering which involved discrimination, or closely scrutinized by having regard to the actual facts and risk of abuse, as in the tax ICI and Marks \& Spencer cases. None of such cases, however, involved a third country. Hence the possible implication that different standards of supervision could exist in the external relations, especially when involving countries like Switzerland, which do not share the goals of the Internal Market and at the time of facts had not yet signed the Agreement with the European Union on the free movement of persons.

Finally, insofar as the free movement of services (because of Art. 49.2 of the EC Treaty) does not apply in the relationship with third countries, one may also wonder how it could legitimately create consequences on other freedoms, such as the movement of capital.

Perhaps, the Fidium Finanz decision will temporarily discourage non-EU suppliers of services from claiming the application of fundamental freedoms, though one may wonder whether it should also prevent EU recipients from doing the same, since it would be harder to extend the principles of this decision in respect of cases where a person invests his/her/its capital to obtain banking and/or financial services from a non-EU supplier. In this respect, the Svensson and Gustavsson case should still represent a precedent to claim that the simultaneous application of the free movement of services and the free movement of capital and payments should be the general rule, therefore still allowing either freedom to remain applicable when the other one is not.

The Court was not given the opportunity to clarify this issue in Scorpio, the third important case decided on 3 October 2006, which concerned a service that an 
EU national received in 1993 (thus before the new provisions on the free movement of capital and payments were included in the EC Treaty) from a supplier of unknown, or at least uncertain or unspecified, nationality.

While applying the same reasoning of Fidium Finanz in respect of the relevance of services received by the EU national, the Court also addressed whether withholding taxes levied on income paid to the nonresident supplier were compatible with fundamental freedoms.

Despite explicitly confirming the Gerritse decision in respect of the right of non-residents to be taxed in the State of performance on their income net of directly linked business expenses, the Court - at least to my surprise - implicitly overruled the latter decision, ${ }^{1}$ when stating in the Scorpio decision that withholding taxes levied in the State of performance are a legitimate and appropriate instrument to ensure that nonresidents do not escape taxation in the State of residence. The clash is even more striking because the Court, following the Opinion of the same Advocate General Léger who analysed the Gerritse precedent, did not even explain the reason for ignoring the need to compare the tax burden applicable to residents under ordinary tax liability at progressive rates with that applicable to non-residents and based on the levying of the withholding tax.

The impact of the Scorpio decision on withholding taxes then even begets revolutionary nuances if we consider that the Court regarded it as a proportionate justification to ensure effective tax collection in the absence of a directive ensuring it for income taxes. Prima facie, one could regard this as the new (and downgraded) version of the argument, first raised by Advocate General Léger in the Schumacker decision, based on the exchange of information directive. Nevertheless, it seems more appropriate to warn that such statement may imply that levying of withholding taxes is no longer proportionate since the directive on mutual assistance in collection of taxes was extended to direct taxes. This conclusion is however hard to reconcile with the complex function of withholding taxes in tax treaties, which in the case of artistes and sportsmen, serve to prevent cases of tax evasion arising from the failure to report foreign-sourced income, but also involve allocation of taxing powers between two States.
Again, the Court overruled its previous case-law when stating in the Scorpio decision that tax authorities may require the issuance of certificates for proving the entitlement to tax exemption. Until this statement, one might have considered this requirement as giving rise to a procedural restriction, by taking into account the Court's previous case-law (especially the Schumacker and Bent Vestergaard decisions) and especially its unwillingness in the Cadbury Schweppes decision to follow the different categories for justifying anti-abuse measures as Advocate General Léger (the same Advocate General who delivered the Opinion on the Scorpio case) had instead suggested. Nevertheless, as in general terms for the mechanism of withholding taxes, one may argue that such certificates should no longer be required for situations falling under the scope of the directive on mutual assistance in tax collection.

3 October 2006. A difficult, but challenging day for the European Court of Justice, which confirmed its solidity and ability to deal with the complexity of tax cases in Europe without compromising legal certainty and protection of rights conferred to each EU nation by the EC Treaty.

However, 3 October 2006 is also a day showing how difficult it has become for the European Court of Justice to reconcile the very complex legal arguments and facts related to each decision in the field of direct taxes.

Finally, 3 October 2006 is a day in which Member States won all cases that may directly or indirectly affect the field of direct taxes. However, this was not the outcome of a policy decision of the European Court of Justice, which remains a body obliged to interpret and apply the law in respect of cases referred to it either through preliminary ruling or infringement procedures. I have so far described the complex factors that determined this outcome and would therefore exclude a clear plan to steer the rudder of European integration towards the Member States. Rather than having unrealistic expectations on future direct tax case-laws, Member States should therefore act to coordinate the exercise of their taxing prerogatives in the framework of a legal pattern that is consistent, efficient and compatible with the primacy of European law. Only this strategy will gradually reduce the influence of the European Court of Justice in the field of direct taxes and lead it back to a more systematic evolution. 